\title{
Pengembangan Media Pembelajaran Berbasis Video Tutorial untuk Meningkatkan Efektifitas Pembelajaran Pada Mata Kuliah Tata Rias Pengantin Indonesia
}

\author{
Mandalika $^{1 *}$ dan Syahril ${ }^{2}$ \\ 1,2Prodi Magister Pendidikan Teknologi dan Kejuruan, Fakultas Teknik, Universitas Negeri Padang \\ "Corresponding author, e-mail: mandalika2211@gmail.com
}

\begin{abstract}
Abstrak-Tata Rias Pengantin Indonesia merupakan salah satu mata kuliah praktek pada jurusan tata rias dan kecantikan yang materi pembelajarannya sulit dipahami mahasiswa karena belum adanya media yang dapat membantu mahasiswa untuk memahami pembelajaran tersebut.Berdasarkan hasil observasi menunjukkan bahwa praktek perkuliahan Tata Rias Pengantin Indonesia sulit dipahami karena media pembelajaran belum efektif. Berdasarkan masalah tersebut, maka penelitian ini memiliki tujuan untuk mengembangkan media pembelajaran yang efektif pada mata kuliah Tata Rias Pengantin Indonesia. Penggunaan metode pada penelitian ini yaitu metode penelitian Research and Development (R\&D) dengan model pengembangan 4-D (Four-D). Tahapan model 4D yaitu define, design, develop, dan disseminate. Media pembelajaran ini akan diterapkan menggunakan aplikasi Edmodo. Simpulan hasil penelitian menunjukkan media pembelajaran yang dihasilkan efektif yang ditunjukkan dengan perbedaan nilai hasil belajar mahasiswa antara kelas kontrol dan kelas eksperimen.Media ini dapat dimanfaatkan sebagai media pembelajaran mata kuliah Tata Rias Pengantin Indonesia.
\end{abstract}

Kata Kunci : Media Pembelajaran, Video Tutorial, dan Tata Rias Pengantin Indonesia.

\begin{abstract}
Indonesian Bridal is a practical learning method at Cosmetology education that difficult to understand by student because learning media that used by lecturer not giving the explanation of theory.Based of observation students in Makeup and Beauty Education for Indonesian Bridal that difficult to understand because a learning media not been effected. Based on that problem, the purpose of this research were developing learning mediaof tutorial video that effective on Indonesian Bridal learning. This research used Research and Development $(R \& D)$ method, and model that was used is 4D model. There was four steps in 4D model, there were define, design, develop, and disseminate. Edmodo applicationappliedto developing learning media. The result concluded that learning media were effective by effectiveness result was have a significant difference between the control class and experimental class. This learning media can be used as a learning media at Indonesian Bridal.
\end{abstract}

Keywords : Learning Media, Tutorial Video, dan Indonesian Bridal.

\section{Pendahuluan}

Pendidikan berperan penting dalam mengembangkan pengaruh positif dan memperbaiki dampak negatifnya secara terusmenerus. Pemanfaatan teknologi dalam menunjang aktifitas pembelajaran pada Perguruan Tinggi merupakan salah satu dampak semakin majunya ilmu pengetahuan yaitu dengan penggunaan media pembelajaran. Beberapa hal sebagai penunjang efektifitas pembelajaran yaitu dengan adanya dukungan media pembelajaran yang memadai dan sesuai dengan kebutuhan pembelajaran.

Media pembelajaran berbasis komputer dapat 
meningkatkan keinginan mahasiswa dalam mengerjakan latihan soal karena terdapat animasi grafis, warna, musik yang merupakan keuntungan dari penggunaan media tersebut [1]. Pada zaman serba teknologi seperti saat ini, komputerisasi merupakan bentuk nyata dari perkembangan zaman yang terus terjadi, begitu juga dengan perkembangan teknologi media pembelajaran memberikan kemungkinan yang cukup berpengaruh dalam mengubah cara belajar seseorang, untuk mendapatkan informasi.

Terdapat banyak metode dan strategi pembelajaran yang bisa digunakan oleh dosen.Seorang dosen juga dituntut membuat suatu inovasi atupun sebuah pengembangan pembelajaran untuk lebih meningkatkan minat dan motivasi mahasiswa dalam pembelajaran. Semua hal yang dapat meningkatkan rangsangan perhatian, pikiran, perasaan dan minat untuk perantara penyampaian pesan daripengirim dan penerima pesan sehinggadapat terjalin proses pembelajaran merupakan arti dari media pembelajaran [2]. Seorang pengajar dalam peningkatan kualitas pembelajaran yaitu dengan pemanfaatan media pembelajaran supaya mahasiswa bisa menambah pencapaian tujuan pembelajaran. Dengan penggunakan media pembelajaran yang sesuai, maka dosen dapat membantu mahasiswa dalam menguasai materi perkuliahan yang diberikan. Penggunaan media pembelajaran juga bisa menerapkan konsep tersebut guna memudahkan pemahaman mahasiswa terhadap konsep agar tercapai tujuan pembelajaran oleh mahasiswa.

Berdasarkan observasi yang penulis lakukan, kemudian mendapatkan hasil bahwa pembelajaran Tata Rias Pengantin Indonesia yang sudah dilaksanakan menggunakan media pembelajaran Powerpoint dalam menyampaikan materi pembelajaran, dengan metode ceramah, tanya jawab, dan praktikum. Media yang digunakan saat perkuliahan antara lain white board, power point, media cetak seperti penampilan gambar dalam pembelajaran yang cenderung lebih banyak menggunakan Powerpoint. Kemudian efektifitas penggunaan media pembelajaran yang sudah digunakan seperti PowerPoint menurut mahasiswa cukup efektif. Kemudian pada pertanyaan selanjutnya tentang kemudahan pemahaman mahasiswa dari penggunaan media PowerPoint tersebut umumnya mahasiswa menjawab media Powerpoint mudah dipahami. Pengetahuan tentang media pembelajaran berupa video tutorial yaitu mahasiswa sudah mengetahui tentang adanya media tersebut. Penggunaan media pembelajaran menggunakan video tutorial pada pembelajaran yang sudah terlaksana yaitu tidak adanya penggunaan media pembelajaran berupa videotutorial yang telah digunakan dosen.

Video tutorial nantinya akan disampaikan melalui aplikasi Edmodo sebagai bentuk pengembangan media pembelajaran yang membuat dosen tidak harus bergantung pada buku ataupun jobsheet dalam penyampaian materi pembelajaran karena dapat menampilkan pembelajaran menggunakan aplikasi yang bisa disimpan secara berkala. Penggunaan media pembelajaran video tutorial yang disampaikan melalui aplikasi Edmodo merupakan media pembelajaran mandiri yang sesuai dengan cara pembelajaran pada pendidikan tinggi. Sehingga peneliti akan mengembangkan media pembelajaran berbasis video tutorial menggunakan aplikasi Edmodo pada mata kuliah rias pengantin Indonesia guna mempermudah mahasiswa dalam menerima materi perkuliahan dan pemahaman materi perkuliahan.

Dalam pembelajaran $70 \%$ mahasiswa menghadapi kesulitan dalam mengikuti proses pembelajaran di kelas karena perbedaan gaya belajar yang tidak sesuai yang diterapkan pada setiap mahasiswa dan $30 \%$ sisanya mahasiswa dapat berpartisipasi dengan baik dalam perkuliahan karena gaya mengajar dan gaya belajar yang diterapkan dosen sesuai dengan gaya belajar mahasiswa [3]. Sebagian besar mahasiswa tidak mampu mengikuti gaya mengajar yang diterapkan oleh dosen dalam mengajar di kelas. Gaya belajar mahasiswa dapat dilihat dari kecerdasan dominan yang dimiliki mahasiswa tersebut, sehingga dosen diharapkan dapat memahami gaya belajar semua mahasiswa yang dilihat dari efektifitas pembelajaran mahasiswa di kelas. Tingkat kemampuan kecerdasan mahasiswa dapat berakibat ketidak sesuaian pada prestasi belajar mahasiswa yang disebabkan oleh kurangnya pemhaaman dosen tentang gaya belajar pada mahasiswa. maka, dosen sebaiknya memfasilitasi proses pembelajaran dengan cara mengetahui dan mengenali gaya belajar setiap mahasiswa.

Media merupakan perantara atau alat bantu yang difungsikan untuk membantu mencapai tujuan dalam belajar dan pembelajaran. Sementara itu media pembelajaran merupakan perantara yang dapat menunjang proses belajar dan mengajar agar lebih baik dan sempurna dengan memperjelas makna dari penyampaian pesan dan memperjelas 
makna dari pesan yangdisampaikan [4]. Materi, tujuan, metode dan kondisi mahasiswa dengan media pembelajaran menjadi suatu hal ynag harus dipertimbangkan dan menjadi pusat perhatian dosen dalam pemilihan dan penggunaan media yang sesuai dengan proses pembelajaran ynag dilaksanakan di kelas. Hal ini juga berkaitan dengan keefektifan dan efisiensi dalam mencapai capaian pembelajaran. Media pembelajaran juga harus disesuaikan dengan karakteristik mahasiswa, karena tidak semua media pembelajaran cocok digunakan untuk segala situasi khususnya pada mahasiswa, tingkat pendidikan mahasiswa, untuk menarik minat mahaisswa, dan seterusnya. Media yang dipilih seharusnya dapat memotivasi mahasiswa dalam belajar sehingga muncul ketertarikan yang lenih kuat untuk belajar secara mandiri dan aktif.

Sehingga dari beberapa macam media tersebut dapat disimpulkan media pembelajaran dikelompokkan dari berbagai aspek. Namun, pada perkuliahan di tata rias dan kecantikan, praktek yang dilakukan kemudian diadakan latihan oleh mahasiswa yang membutuhkan contoh langkah kerja yang dilakukan sehingga dibutuhkan media pembelajaran yang dapat memberi contoh dan pemahaman pada mahasiswa yaitu media video pembelajaran.

Video tutorial merupakan gambaran rangkaian tahapan proses untuk membantu pemahaman tentang suatu materi yang ditayangkan oleh pengajar yang isinya adalah materi pembelajaran sebagai bimbingan untuk peserta didik [5]. Sedangkan media video pembelajaran merupakan sebuah software komputer berisi materi pelajaran dengan tujuan untuk memberikan pemahaman secara keseluruhan kepada mahasiswa tentang materi pelajaran yang sedang dipelajari [6].

Video adalah alat yang mampu menampilkan pemaparan proses, menyajikan informasi, berisi penjelasankonsep yang sulit, mengajarkan keterampilan, mempersingkat ataumemperlambat waktu [7]. Video tutorial membimbing mahasiswa dalam pemahaman sebuah materi secara visual. Mahasiswa dapat berpartisipasi secara aktif dalam mengikuti seluruh kegiatan praktek pembelajaran yang sesuai dengan yang diajarkan dalam video. Tutorial merupakan pembimbingan kelas yang dilakukan seorang pengajar kepada sekelompok mahasiswa [8]. Terdapat beberapa syarat penentu video tutorial dapat digunakan menjadi sebuh medi pembelajaran sehingga dapat membantu proses pembelajaran menjadi lebih mudah digunakan, efektif untuk meningkatkan hasil belajar, efisien dalam penggunaan waktu, dan tepat digunakan sesuai kebutuhan mahasiswa.

Video tutorial memiliki kelebihan yaitu tampilannya menarik perhatian, dengan perekaman video beberapa penonton memperoleh informasi dari ahlinya, demonstrasi biasanya sulit disiapkan dan direkam, pada waktu belajar dosen dapat memusatkan perhatian mahasiswa pada penyajiannya, efisiensi waktu dan rekaman yang sudah dibuat dapat diputar ulang, dapat mengamati objek, lebih dekat dengan objek yang sedang bergerak, keras atau lemahnya suara bisa disesuaikan, gambar proyeksi bisa dibekukan (pause) untuk mengamati gambar dengan seksama [9].

Terkait fungsinya sebagai pendukung metode pembelajaran, dalam sistem media pembelajaran online ini ada beberapa aspek yaitu soal-soal, materi yang dapat disediakan dengan bentuk modul dan dilengkapi dengan cara pengerjaan yang ditampilkan, komunitas, mahasiswa dapat memberi informasi yang saling menguntungkan serta mengembangkan komunitas pembelajaran online, pengajar online, dalam melakukan latihan praktek dosen selalu online untuk memberikan arahan kepada mahasiswa, dapat bekerja sama, dilakukan secara bersamaan tanpa terkendala oleh jarak dengan adanya software yang dapat mengatur pertemuan secara online, media dalam penyampaianmateri dapat menarik minat dalam perkuliahan menggunakan teknologi audio dan visual.

Aplikasi yang digunakan untuk peyampaian materi pelajaran online salah satunya adalah aplikasi Edmodo yang di download dari internet. Edmodo merupakan jejaring sosial untuk pembelajaran berbasis learning management system (LMS). Edmodo memberikan akses untuk berkomunikasi, berbagi informasi, berkolaborasi, dan aplikasi pembelajaran bagi mahasiswa dan dosen. Edmodo memiliki fungsi pada proses pembelajaran, yaitu sebagai pelengkap, pengganti, dan pendamping [10].

Kelebihan dari aplikasi Edmodo yaitudapat membantu dosen dalam memberikan pemberitahuan dalam grup atau memberi tes yang sifatnya online yang memungkinkan mahasiswa 
untuk mengirim artikel yang sesuai dengan kurikulum kelas dan berkaitan dengan perintah dosen, aplikasi Edmodo yang digunakan dosen dapat mengembangkan proses pembelajaran di kelas dengan cara diskusi sehingga mahasiswa dapat berkomunikasi antara satu dengan yang lainnya diwaktu yang bersamaan, dosen juga dapat menggunakan aplikasi Edmodo untuk memberikan perintah, penetapan, dan membicarakan dengan mahasiswa secara online diwaktu yang sama pada waktu yang bersamaan [11].

Edmodo menyediakan cara untuk berbagi konten pendidikan, pengelolaan tugas, juga dapat memberikan pemberitahuan untuk setiap aktivitas yangdilakukan antara dosen dan mahasiswa sertamenumbuhkan kerjasama di dalam kelas. Edmodomemberikan kemudahan bagi dosen dalam membuat sebuah kelas virtual yang disesuaikan dengan kondisi nyata pembelajaran dalam kelas.

Edmodo dikembangkan dengan metode pembelajaran yang adaptif sesuai dengan kebutuhan mahasiswa. Pembelajaran menggunakan aplikasi edmodo berorientasi pada mahasiswa, memberikan akses pada mahasiswa untuk mengembangkan kemampuan secara mandiri dan tidak hanya menekankan pada kompetensi tetapi juga kreatifitas dalam pemahaman konsep. Idealnya dosen dan mahasiswa selalu mengakses berbagai infomasi dengan cepat, bertanggung jawab dan sesuai harapan.

\section{METODA}

Model pengembangan dari penelitian ini yaitu menggunakan media pembelajaran dengan metode $\mathrm{R} \& \mathrm{D}$ atau dikenal dengan Research and development. Metode penelitian pengembangan merupakan suatu penelitian yang dilakukan dengan mengembangkan produk yang sudah ada maupun pembuatan produk baru dan kemudian dilakukan uji efektifitas produk agar dapat digunakan dalam proses pembelajaran [12]. Metode penelitian ini merupakan metode yang digunakan untuk menghasilkan suatu produk tertentu dan kemudian menguji keefektifan produk tersebut.

Penelitian ini digunakan untuk mengetahui apakah media yang dikembangkan dalam proses pembelajaran sudah efektif untuk meningkatkan pengetahuan mahasiswa melalui tes soal hasil belajar. Lokasi penelitian ini dilaksanakan di Program Studi Pendidikan Tata Rias dan Kecantikan, FPP, UNP tahun ajaran 2019/2020.

\section{Uji Efektifitas}

Pengujian efektifitas dilakukan untuk mengetahui keefektifan dari penggunaan media pembelajaran video tutorial mata kuliah Tata Rias Pengantin Indonesia setelah dikembangkan yang dilihat dari tes hasil belajar mahasiswa menggunakan media pembelajaran video tutorial.

Untuk menentukan keefektifan mediaovideo tutorial pada mata kuliah Tata Rias Pengantin Indonesia maka mahassiswa diberi tes berupa soal mengenai materi. Soal tes yang diberikan terlebih dahulu diuji validitas soal, reliabilitas, indeks kesukaran dan uji daya beda soal.

\section{A. Validitas soal}

Uji validitas butir soal dihitung menggunakan rumus koefisien korelasi biserial [14]. Soal tes dinyatakan valid apabila dapat mengukur apa yang hendak diukur dan hasilnya sesuai dengan kriteria.

Uji validitas soal dilakukan dengan rumus product moment sebagai berikut:

Harga $r_{p b i}$ kemudian dikonsultasikan dengan nilai $r_{\text {tabel }}$ pada tarafsignifikan $5 \%$.Apabila $r_{p b i}>r_{\text {tabel }}$, maka butir soal tes tersebut valid Sebaliknya, jika $r_{p b i}<r_{\text {tabel }}$, maka butir soal tes tersebut tidak valid.

\section{B. Reliabilitas Soal}

Sebuah tes dikatakan reliabilitass apabila dilakukan menggunakan tes secara berulang apabila hasil hasil perngukurannya menggunakan tes kepada subjek yang sama maka akan memberikan hasil yang tetap [15]. Reliabilitas adalah instrumen yang menunjukkan konsistensi sebuah tes.Sehingga sebuah tes dikatakan reliabel apabila hasilnya memiliki ketetapan.

Kriteria dalam pengujian reliabilitas adalah dikonsultasikan dengan tabel 1 .

\section{Indeks Kesukaran}

Tingkat kesukaran soal adalah nilai yang menunjukkan sukar atau mudahnya suatu soal tes [16]. Kategori penghitungan indeks kesukaran soal dapat dilihat pada Tabel 2. 
Tabel 1. Kriteria Pengujian reliabilitas

\begin{tabular}{|l|l|l|}
\hline No & Reliabilitas & Klasifikasi \\
\hline 1 & $0,00 \leq \mathrm{R} \leq 0,199$ & Sangat rendah \\
\hline 2 & $0,20 \leq \mathrm{R} \leq 0,399$ & Rendah \\
\hline 3 & $0,40 \leq \mathrm{R} \leq 0,599$ & Cukup \\
\hline 4 & $0,60 \leq \mathrm{R} \leq 0,799$ & Tinggi \\
\hline 5 & $0,80 \leq \mathrm{R} \leq 1,00$ & Sangat Tinggi \\
\hline
\end{tabular}

Tabel 2. Indeks Kesukaran

\begin{tabular}{|l|l|}
\hline Interval & Kategori \\
\hline $0,00<\mathrm{P}<0,30$ & Sukar \\
\hline $0,30<\mathrm{P}<0,70$ & Sedang \\
\hline $0,70<\mathrm{P}<1,00$ & Mudah \\
\hline
\end{tabular}

\section{Uji Daya Beda}

Uji daya beda soal merupakan suatu indikator untuk membedakan mahasiswa yang pandai dan yang kurang pandai [17]. Uji daya beda dilakukan untuk membedakan kategori mahasiswa antara yang berkemampuan tinggi dengan mahasiswa yang berkemampuan rendah .

2. Analisis Efektifitas Media Pembelajaran Video

Tutorial mata kuliah Tata Rias Pengantin Indonesia

\section{A. Uji Normalitas}

Uji normalitas dilakukan menggunakan rumus persamaan kolmogorov-smirnov dengan bantuan aplikasi SPSS 21 pada taraf sigifikan besar dari 0,05 maka dinyatakandata berdistribusi secara normal.

\section{B. Uji Homogenitas}

Uji homogenitas pada penelitian ini menggunakan rumus Levene-Statistic dengan bantuan aplikasi SPSS 21. Jika nilai signifikan besar dari 0,05 maka dinyatakan homogen.

\section{HASIL DAN PEMBAHASAN}

Penelitian ini bertujuan untuk menghasilkan media pembelajaran berbasis video tutorial yang efektif. Pada penelitian ini metode yang digunakan yaitu Research and Development dengan model pengembangan yaitu Four-D (Define, Design, Develop, and Disseminate).

Tahap define (pendefinisian) mencakup analisis kebutuhan, analisis materi, dan analisis mahasiswa. tahap analisis kebutuhan ini berguna untuk mengidentifikasi masalah yang ada selama pembelajaran, dan melihat solusi seperti apa yang dibutuhkan. Tahap analisis materi yaitu meidentifikasi materi pembelajaran yang sulit dipahami mahasiswa selama pembelajaran. tahap analisis mahasiswa yaitu wawancara kepada mahasiswa.

Tahap Design (perancangan) pada tahap ini dilakukan perancangan media video tutorial. Tahap pertama yang dilakukan yaitu penyusunan standar materi yang dilakukan berdasarkan SAP rias pengantin Bali dan dilanjutkan dengan pembuatan kisi-kisi. Pemilihan media yang sesuai ddengan tujuan pembelajaran. penulisan naskah yaitu membuat naskah video tutorial yang sesuai dengan materi pembelajaran. pengambilan gambar dan suara untuk pembuatan video tutorial. Selanjutnya proses editing yaitu penggabungan dari beberapa video dan dimasukkan suara dan teks penjelasan. Dilanjutkan dengan menerbitkan media pembelajaran video tutorial pada mahasiswa pendidikan tata rias dan kecantikan. Di akhir tahapan design yaitu uploading media video tutorial ke dalam aplikasi edmodo untuk di akses mahasiswa secara mandiri.

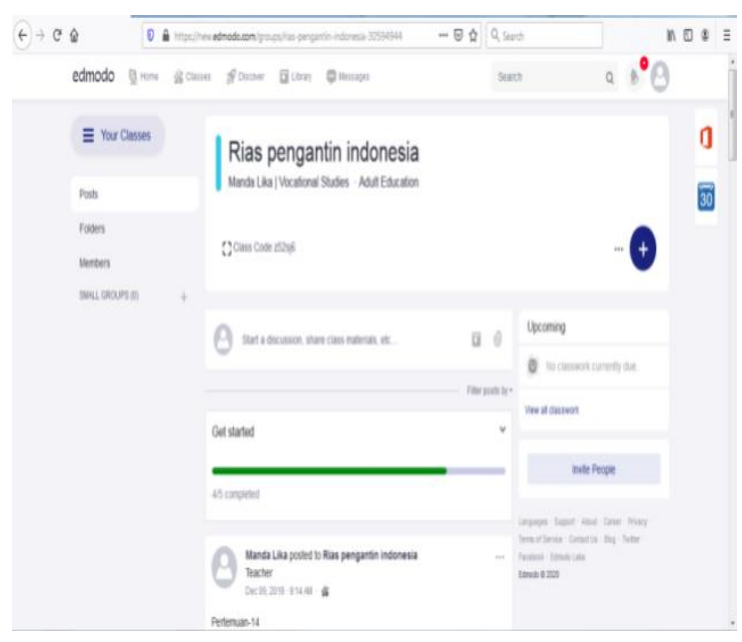

Gambar 1. Tampilan media pembelajaran

Gambar 1 merupakan tampilan awal kelas mata kuliah tata rias pengantin Indonesia pada aplikasi edmodo yang terdapat video tutorial rias pengantin Indonesia di dalamnya. Video tutorial juga berisi tahapan pengerjaan rriasan dan penataan rambut.

Gambar 2 merupakan tampilan awal video tutorial rias pengantin yang berisi tahapan pengerjaan riasan wajah pengantin. Tahapan rias pengantin ditampilkan menggunakan gambar bergerak yang berisi suara penjelasan dan teks sebagai keterangan penjelas mengenai tahapan pengerjaan riasan. 


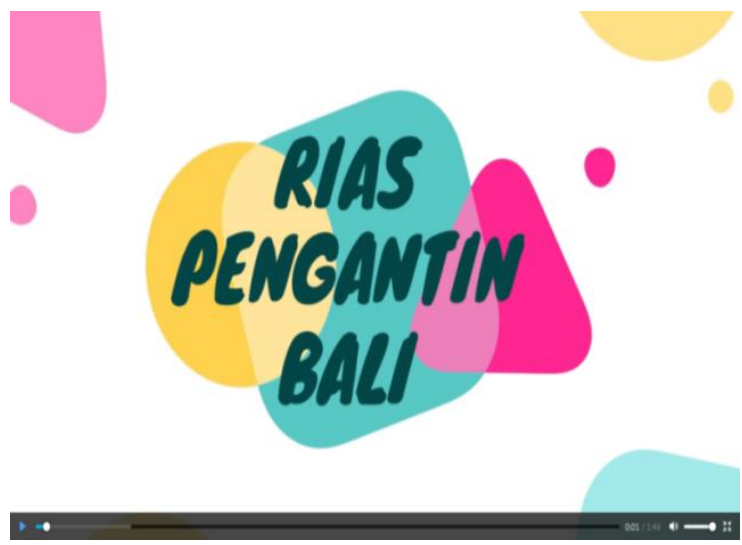

Gambar 2. tampilan awal video tutorial rias

Gambar 3 merupakan tampilan awal video tutorial pembuatan sanggul atau penataan rambut yang berisi tahapan pengerjaan dan alat bahan yang dibutuhkan untuk membuat penataan rambut yang sesuai dengan tema riasan pengantin Indonesia yang sedag dipelajari.

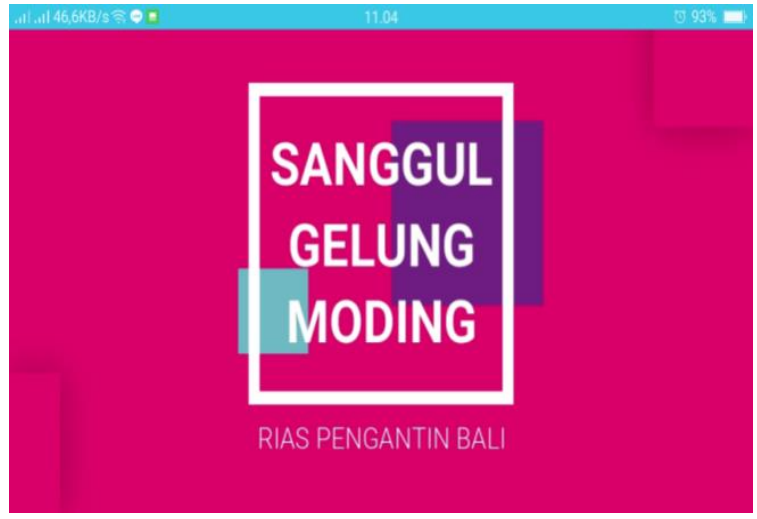

Gambar 3. tampilan awal video tutorial sanggul

Tahap Pengembangan (develop) tahap ini bertujuan untuk menghasilkan media pembelajaran yang efektif. Uji efektifitas ini dilakukan dengan memberikan soal tes kepada mahasiswa yang sudah diuji validitas soal, indeks kesukaran, daya beda, dan reliabilitasnya yang dinyatakan layak untuk di uji kepada mahasiswa.

Pengumpulan data pada penelitian ini, berdasarkan dari hasil nilai belajar mahasiswa yang menggunakan video pembelajaran rias pengantin Indonesia dengan mahasiswa yang tidak menggunakan media pembelajaran rias pengantin Indonesia. selanjutnya, setelah melakukan tes soal kemudian dilkukan penghitungan t-test terlebih dahulu menggunakan uji normalitas dan dilanjutkan dengan uji homogenitas. Tabel 3 mennunjukkan nilai rata- rata hasil belajar mahasiswa kelas kontrol dan kelas eksperimen.

Tabel 3. Hasil Belajar mahasiswa

\begin{tabular}{|l|l|l|}
\hline No & Kelas & Hasil belajar \\
\hline 1 & Kelas kontrol & 66,93 \\
\hline 2 & Kelas eksperimen & 80,13 \\
\hline
\end{tabular}

Berdasarkan Gambar 4 meunjukkan perbedaan hasil belajar antara kelas kontrol dan kelas eksperimen. Pada kelas kontrol yang tidak menggunakan media pembelajaran video tutorial didapatkan rata-rata hasil belajar mahasiswa yaitu 66,93 sedangkan kelas eksperimen yang menggunakan media pembelajara video tutorial didapatkan rata-rata hasil belajar mahasiswa yaitu 80,13 yang artinya terdapat perbedaan rata-rata hasil belajar mahasiswa kelas kontrol dan kelas eksperimen. kemudian, setelah didapatkan hasil tes, maka dilanjutkan dengan uji analisis data dengan uji $\mathrm{T}$ yang meliputi uji normalitas dan uji homogenitas.

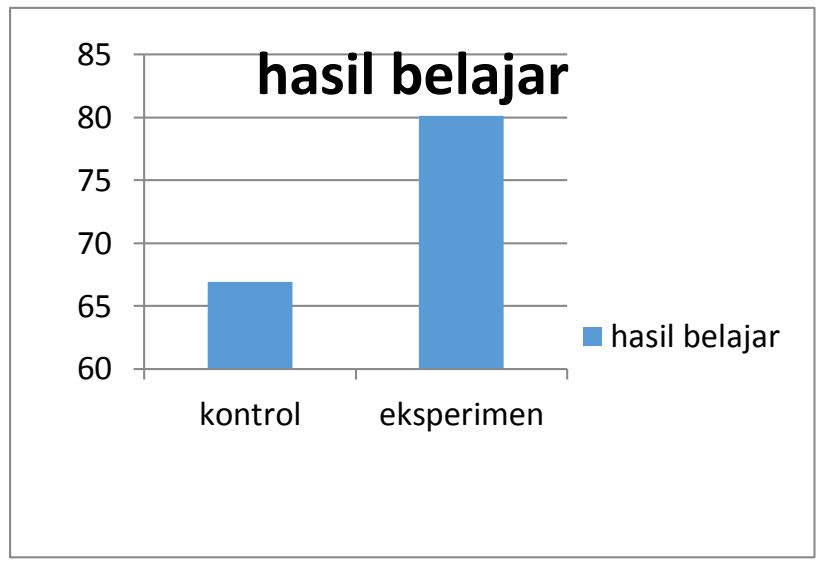

Gambar 4. hasil belajar mahasiswa

Hasil uji normalitas data yaitu pada kelas kontrol sebesar 0,386, yang artinya data berdistribusi normal karena taraf signifikansinya 0,05, karena nilai normalitas lebih besar dari signifikansi $0,386>0,05$ artinya data berdistribusi normal. Pada uji coba kelas eksperimen, didapatkan hasil 0,688 yang besar dari signifikansinya yaitu 0,05 yang artinya $0,688>0,05$ data berdistribusi normal di kelas eksperimen.

Berdasarkan uji homogenitas yaitu nilai homogenitas data yaitu 0,283 yang besar dari signifikansi 0,05. Hasil homogenitas data yaitu $0,283>0,05$ yang memiliki variansi yang sama (homogen) dan dapat dilakukan dengan uji hipotesis. 
Tabel 4. hasil uji coba produk

\begin{tabular}{|l|l|l|}
\hline & $\begin{array}{l}\text { Uji } \\
\text { normalitas }\end{array}$ & $\begin{array}{l}\text { Uji } \\
\text { homogenitas }\end{array}$ \\
\hline Kelas kontrol & 0,568 & 0,533 \\
\hline Kelas eksperimen & 0,619 & 0,782 \\
\hline
\end{tabular}

Uji hipotesis dilakukan untuk melihat perbedaan mahasiswa menggunakan media dengan mahasiswa yang tidak menggunakan media. Hasil pengujiannya yaitu t hitung sebesar 6,482 dan $\mathrm{t}$ tabel sebesar 2,062. Hipotesis yang diajukan dapat diterima karena $t$ hitung $>t$ tabel yaitu $6,482>2,062$. Uji hipotesis ini menyatakan bahwa terdapat perbedaan antara kelas kontrol dan kelas eksperimen pada pembelajaran mata kuliah Tata Rias Pengantin Indonesia pada mahasiswa Pendidikan Tata Rias dan Kecantikan.

\section{KESIMPULAN}

Berdasarkan analisis data dan pembahasan maka dapat disimpulkan bahwa media pembelajaran menggunakan video tutorial pada mata kuliah Tata Rias Pengantin Indonesia yang dikembangkan oleh peneliti menghasilkan media pembelajaran yang efektif digunakan pada proses pembelajaran mahasiswa.Uji efektifitas data diuji dengan normalitas data yaitu dengan nilai normalitas lebih besar dari signifikansi yang artinya data berdistribusi normal pada kelas kontrol. Pada uji coba kelas eksperimen, didapatkan hasil yang menunjukkan data berdistribusi normal di kelas eksperimen. Hasil homogenitas datayang memiliki variansi yang sama (homogen) dan dapat dilakukan dengan uji hipotesis. Uji hipotesis ini menyatakan bahwa terdapat perbedaan antara kelas kontrol dan kelas eksperimen pada pembelajjaran mata kuliah Tata Rias Pengantin Indonesia pada mahasiswa Pendidikan Tata Rias dan Kecantikan. Sehingga media pembelajarn video tutorial ini efektif digunakan untuk meningkatkan hasil belajar mahasiswa.

Penelitian pengembangan ini telah menghasilkan media pembelajaran video tutorial yang efektif sehingga dapat digunakan untuk meningkatkan pemahaman materi dan keterampilan dalam praktek perkuliahan mahasiswa dalam pembelajaran Rias Pengantin Indonesia. proses penggunaan media pembelajaran video tutorial ini dapat meningkatkan efektifitas dan efisiensi penggunaan waktu dalam proses pembelajaran dapat terlaksana secara maksimal. Media pembelajaran video tutorial yang ditampilkan melalui aplikasi edmodo ini memiliki kemudahan dalam pembelajran karena dapat diakses secara mandiri oleh mahasiswa dan dapat memanfaatkan teknologi yang ada karena diakses melalui smartphone mahasiswa dan memaksimalkan pemanfaatan sarana dan prasarana yang sudah disediakan Universitas Negeri Padang.

\section{DAFTARPUSTAKA}

[1] Wena,M. Strategi Pembelajaran Inovatif Kontemporer Suatu Tinjauan Konseptual Operasional. Jakarta : PT. Bumi Aksara. 2009.

[2] Sadiman, Arief S dkk, Media Pembelajaran: Pengertian, Pengembangan dan Pemanfaatannya, Jakarta: PT Rajawali Pers. 2009.

[3] Musrofi. Melesatkan Prestasi Akademik Siswa: Cara Praktis Meningkatkan Prestasi Akademik Siswa Tanpa Kekerasan dan Tanpa Harus Menambah Jam Belajar.Yogyakarta: PT Pustaka Inttan Madani, Anggota IKAPI. 2010.

[4] Kustandi, dkk. Media Pembelajaran: Manual dan Digital. Bogor: Ghalia Indonesia. 2011.

[5] Trianto. Mendesain Model Pembelajaran Inovatif Progresif. Jakarta : Kencana. 2009.

[6] Rusman, dkk. Pembelajaran Berbasis Teknologi Informasi dan Komunikasi. Jakarta: PT. Raja Grafindo Persada. 2011.

[7] Kustandi, Cecep. Media Pembelajaran Manual dan Digital Edisi Kedua. Bogor : Ghalia Indonesia. 2013.

[8] Tim Pustaka Phoenix. Kamus Besar Bahasa Indonesia (cetakan keenam). Jakarta : PT. Media pustaka Phoenix. 2012.

[9] Airiyah, Z dan Puspasari. Penggunaan Edmodo sebagai Media Pembelajaran e-learning pada Mata Pelajaran Otomatis Perkantoran di SMKN 1 Surabaya. Jurnal Administrasi Perkantoran : UNS. 2015

[10] Dessler, Gary. Manajemen Sumber Daya Manusia. Jakarta : Indeks. 2011.

[11] Edi Setiyo, Zulhermanan Zulhermanan, Harlin Harlin "Pengembangan Media Pembelajaran Berbasis Flash Flip Book pada Mata Kuliah Elemen Mesin 1 di Program Studi Pendidikan Teknik Mesin Universitas Sriwijaya". Vol 18 No 1 (2018): INVOTEK: Jurnal Inovasi, Vokasional, dan Teknologi. 
[12] Sugiyono. Metode Penelitian Pendekatan Kualitatif, Kuantitatif dan $R \& D$. Bandung : Alfabeta. 2008.

[13] Arikunto, Suharsimi. Penelitian Tindakan Kelas. Jakarta: Bumi Aksara. 2015.

[14] Sugiyono. Metode Penelitian Kuantitatif, Kualitatif dan R\&D. Bandung: Alfabeta. 2012.

[15] Arikunto, Suharsimi. Manajemen Penelitian. Jakarta: Rineka Cipta. 2005.

\section{Biodata Penulis}

Mandalika, lahir di Bukittinggi, 22 Juni 1995. Sarjana Sains Terapan di Jurusan Pendidikan Tata Rias dan Kecantikan FPP UNP 2017. Tahun 2019 memperoleh gelar Magister Pendidikan di jurusan Pendidikan Teknologi dan Kejuruan Program Pascasarjana UNP dengan bidang konsentrasi Pendidikan Kesejahteraan Keluarga.

Syahril, lahir di Maninjau, 6 Mei 1964. Sarjana Teknik pada Jurusan Teknik Mesin IKIP Padang tahun 1989. Tahun 1997 memperoleh gelar Magister di Jurusan Teknik Mesin Fakultas Teknik UGM Yogyakarta. Master Engineering (MSCE), in Dept. Mechanical and Material Engineering, UKM Malaysia pada tahun 2005. Doctoral (Ph.D) in Vocational and Technical Education, Faculty of Education, UKM Malaysia pada tahun 2010. Staf Pengajar di Teknik Mesin Fakultas Teknik UNP. 